\title{
Luselønn og legemangel
}

\author{
«Når Bodø sykehus nu for 4de gang er flyttet inn i ny bygning...» Slik innleder overlege Friis i Tidsskriftet \\ nr. 7/1929 sin gjennomgang av sykehusets historie. I den idylliske bygningen under behandlet man ved midten \\ av 1800-tallet 60-80 pasienter i året for «vesentlig veneriske sykdommer og endel infeksjonssykdommer som \\ tyfus og difteri». Problemet var å få fylt legestillingen (Tidsskr Nor Lægeforen 1929; 49: 333-49).
}

\section{Hygiene, social medisin, lageforhold m. v.}

\section{Bodø sykehus.}

Av overlæge N. Friis, Bodø.
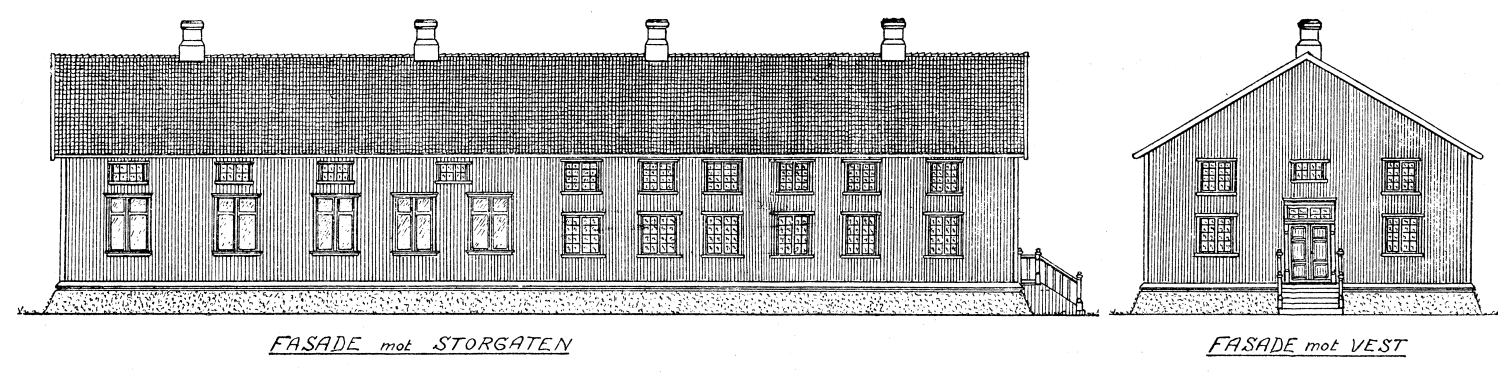

FASADE mot VEST

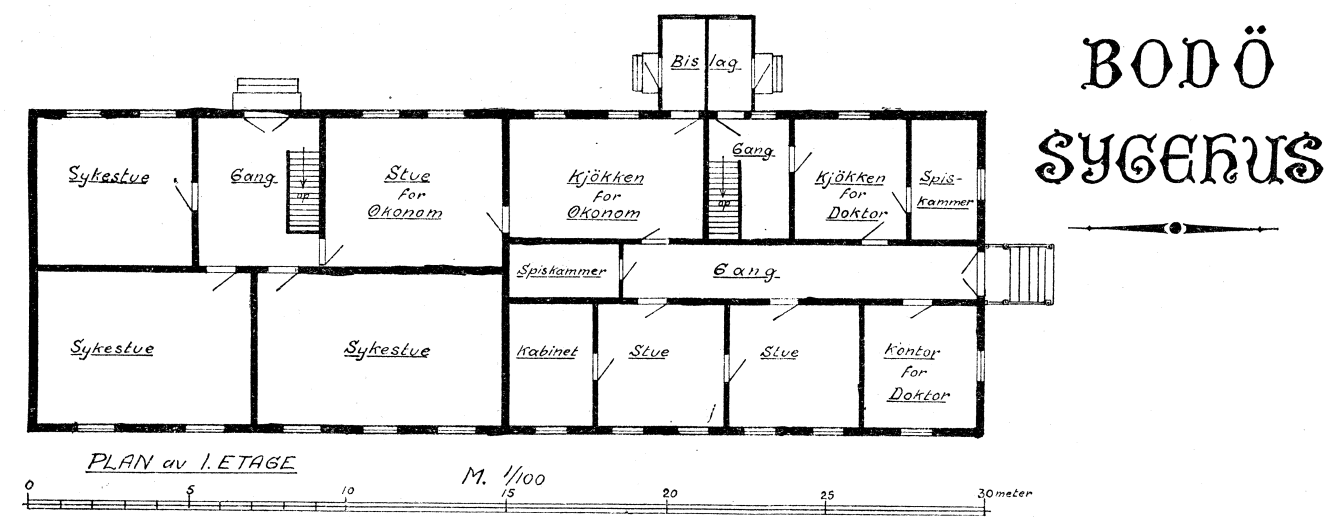

Bodø sykehus 1833-1880.

Som læge ved sykehuset fungerte den hele tid distriktslægen, som foruten fri bolig herfor oppebar en lønn av 30 spd. årlig. Dertil hadde han for bruk av instrumenter vært tillagt $10 \mathrm{spd}$. Distriktet omfattet så sent som i 70-årene foruten Bodø by med dengang 1200 innbyggere Bodø landsogn (Bodin), Gildeskål og Beiern med 6580, tilsammen 7781 innbyggere. Distriktslægen utførte dertil også lægetjeneste ved de betydelige storsillfiskerier, som dengang foregikk i Salten.

For å betjene dette store distrikt var distriktslægen derfor fraværende på reiser i flere dager og lægetilsynet ved sykehuset blev derefter. «For at bevirke dels Lægetjenesten ved Sygehuset tilfredsstillende præsteret, dels ogsaa for at Distriktslægen udelukkende kan ofre sig for landdistrikterne, og Lægehjelp for disse med større Sikkerhed kan paaregnes end hidtil» besluttet amtsformannskapet i 1874 å ansette egen sykehuslæge med en årlig lønn av 250 spd.

Den ansatte sykehuslæge tiltrådte 1 . september 1875 , men opsa allerede på grunn av for liten lønn stillingen den 16. mai nestefter.
Det meldte sig nu ingen ansøkere til posten. Amtmanden gjorde selv forsøk i Kristiania på «at vinde en Kandidat for Posten, men blev overalt modtaget med den Besked, at Aflønningen var for liden til at nogen ville entrere paa samme». Lønnen blev nu forhøiet til 400 spd., og den først ansatte læge overtok påny stillingen, men opsa den atter med fratredelse den 8. august. Han forblev dog i stillingen til den 19. januar 1877, idet han i denne tid under ledigheten også bestyrte Bodø distriktslægestilling. Posten blev pånytt avertert ledig med en høiere lønn uten at nogen ansøker meldte sig.

Imidlertid blev ved den tid Bodø lægedistrikt delt således at Bodø prestegjeld, Bodø by deri innbefattet, utgjorde et distrikt og Beiarn og Gildeskål et distrikt. Lægens fravær på reiser kom således ikke nu i samme grad som før til å hindre ham fra sykehusets forsvarlige tilsyn, hvorfor den gamle ordning med distriktslægen som sykehuslæge atter blev etablert, og nogen forandring heri blev der ikke før i 1911. 